\title{
Improving of Global Solar Radiation Forecast by Comparing Other Meteorological Parameter Models with Sunshine Duration Models
}

irfan Uçkan ( $\square$ irfanuckan@yyu.edu.tr)

Van Yuzuncu Yil University: Van Yuzuncu Yil Universitesi https://orcid.org/0000-0003-3679-5661

Kameran Mohammed KHUDHUR

Van Yuzuncu Yil University: Van Yuzuncu Yil Universitesi

\section{Research Article}

Keywords: Prediction, Solar energy, Solar radiation, Sunshine duration

Posted Date: January 17th, 2022

DOI: https://doi.org/10.21203/rs.3.rs-853866/v1

License: (c) (1) This work is licensed under a Creative Commons Attribution 4.0 International License.

Read Full License

Version of Record: A version of this preprint was published at Environmental Science and Pollution Research on January 24th, 2022. See the published version at https://doi.org/10.1007/s11356-02218781-3. 


\title{
Improving of Global Solar Radiation Forecast by Comparing Other Meteorological Parameter Models with Sunshine Duration Models
}

\author{
İfan UÇKAN $^{1 *}$, Kameran Mohammed Khudhur ${ }^{1}$ \\ ${ }^{1}$ Yuzuncu Yil University, Department of Mechanical Engineering, 65080, Van, Turkey.
}

\section{ABSTRACT}

The solar radiation is affected by many physical factors such as air molecules, water vapor content, dust scattering, and other atmospheric components until it reaches to the earth. Therefore, these factors have negative effects on the measurement of sunshine duration. The aim of this study is to compare sunshine duration based models and the other meteorological parameters based models, and to develop new forecasting models. The estimation and comparison of global solar radiation has been made by using twenty four empirical models including three new models for different location named Arbil, Dohuk, and Sulaimania of Northern Iraq. The reason of using these different locations is to test the accuracy of the other meteorological parameters models by comparing the sunshine duration models for different region. Mostly common statistical errors values are used to evaluate the performance of the estimation models and to identify the models that will give the closest results to the actual values. According to the results, it was seen that the models based on other meteorological parameters has better predictions than the models based on the sunshine duration. While the $\mathrm{R}^{2}$ value of the best models depending on the sunshine duration ranged from 0.97 to 0.99 , the $\mathrm{R}^{2}$ values of the best models of other meteorological parameters are above 0.99 . Furthermore, it is observed that the new proposed models provide better estimates of global solar radiation at different locations than all models used in this study.

Keywords: Prediction, Solar energy, Solar radiation, Sunshine duration

1*Corresponding author: irfanuckan@yyu.edu.tr, Yuzuncu Yil University Mechanical Engineering Department, 65080,Van, Turkey 


\section{Introduction}

Global solar radiation coming to earth has an important place in the world solar system. The information on this subject has an inevitable significance in terms of agriculture, environment and energy.

Today, solar radiation and renewable energy are imperative energy technologies, which can assist handling the issues climate change. When the use of renewable energy sources are increased, the results of these are that the reduction of $\mathrm{CO}_{2}$ emissions, the cut of local air contamination, the creation of high value occupations and diminish the dependency of a country on importations of fossil energy. When the solar energy compared with other fossil-based energy sources, it can be seen that the solar energy, an important source of energy, does not harm the environment and has no effect on global warming (Jiandong et al. 2015). Solar radiation data is especially important for manufactures, designers of solar energy systems, architects and agriculturists. But solar radiation measurements have been made in very few places around the world. There are several reasons for this such as installation cost, maintenance, and calibration (Hunt et al. 1998). But, the measurement of solar radiation can only be measured in various regions of developing countries.

Since solar radiation measurements were not made for each region on the earth, many models have been developed for the regions where there were no measuring stations. The development of global solar radiation models is increasing day by day. However, these models may give different results in different regions. Therefore, it is necessary to develop models for each region as much as possible. Therefore, a study was conducted to develop solar radiation models for India (Makade et al., 2021). In the absence of solar radiation measurement data, several models have been developed to obtain solar radiation more easily. There are several empirical methods used to estimate global solar radiation, which are expressed as an empirical function of one of the such parameters: Sunshine hours, Cloudiness, Meteorological parameters. Therefore, solar radiation prediction models for unmeasured regions of solar energy have been developed to 
facilitate the use of solar radiation for these regions (Elagib and Mansell. 2000). Furthermore, various methods such as empirical methods (Chukwujindu. 2017; Jahania et al. 2017), artificial intelligence methods (Peng et al. 2020; Benghanem 2009) and based on satellite data (Janjai 2011; Bamehr and Sabetghadam, 2021) have been developed to eliminate the lack of solar radiation measurement. The first empirical model was found by Angstrom (Angstrom 1924), who derived a linear relationship between the ratio of average daily global radiation to the corresponding value on a completely clear day at a given location and the ratio of average daily sunshine duration to the maximum possible sunshine duration (Paulescu 2008). However, the solar radiation under clear sky conditions involves some ambiguity. Thus, Prescott (1940) suggested replacing it for the extraterrestrial radiation on a horizontal surface, an amount that has also the advantage of being estimated theoretically (Manzano et al. 2015). In the literature many models have tried to estimate the solar radiation on the earth using parameters such as ambient temperature (Fan et al. 2018; Tao et al., 2021), sunshine duration (Chen et al. 2013; Li et al. 2011; Suehrcke et al. 2013 ) cloud cover (Ehnberg and Bollen 2005), relative humidity (Liu et al. 2017; Su et al. 2021), and rainfall (Liu and Scott 2001). For global solar radiation calculations, temperature-dependent models can be measured easily, so they are very practical and interesting. However, due to the fact that only temperature-dependent models are not sufficient in humid regions, higher-quality models have been developed by taking into account relative humidity values (Rehman and Mohandes 2008 2001). Hassan et al. (2016) developed new models depending on the outdoor temperature as an alternative to sunshine duration models generally used in solar radiation estimation since solar radiation measurement is not possible in all locations on the earth. Furthermore, some models based on measurement data for various time intervals have been developed for further improve the accuracy (Chen et al. 2004; Zhou et al. 2018; Yao et al. 2014). Also, different models have been developed in the literature by using different regression equations such as logarithmic, exponential, linear, and quadratic depending on sunshine duration (Almorox and Hontoria 2004; Ampratwum and Dorvlo 1999). 
82 humidity, and can be easily accessed at each station. However, it may not be possible to find the data depending on the sunshine duration at all stations (Bakırc1 2009; El-Metwally 2005). In addition, solar radiation is affected by many physical factors such as albedo, air molecules scattering, water vapor content, dust scattering, and other atmospheric components until it reaches the earth. Therefore, these factors have negative effects on the measurement of sunshine duration. The challenge nowadays is to develop models that are an important issue for solar applications, achieving good performances and significantly reducing forecast error rates at different time scales. Some researchers have examined the sunshine duration and temperature based models separately and compared these models with each other. As a result of these studies, they showed that the temperature-dependent model results performed better than sunshine duration based models (Liu et al. 2009; Isıkwue et al 2013). In addition, relative humidity, geographic location, air temperature based models recorded in the vast majority of meteorological stations are applicable models, and in some studies (Allen 1997; Li et al. 2013), these meteorological data have been used in solar radiation estimation models.

In this context, some of the other meteorological parameters based models and sunshine duration based models taken from the literature were examined and compared with each other. Furthermore, this study presents new other meteorological-based models for estimating global solar radiation as alternatives to the widely used sunshine-based models owing to it performs closer to real results.

Although the oil production in the Northern Iraq is very high, it is a less developed region. In this area, the use of petroleum products in domestic and industrial electricity generation causes serious environmental pollution and causes a significant increase in the level of $\mathrm{CO}_{2}$ (Birol 2017; Al-Douri 2016). Nowadays; renewable energy sources, especially solar energy, are increasingly entering our lives and solar radiation data is needed due to increasing use of solar energy systems. 
The use of solar energy with high energy potential is very important to reduce the level of harmful gases in this region. But there is not much work done in this area about solar radiation data.

The aim of the presented work is that prediction of global solar radiation is generally done by developing models based on sunshine duration in the literature. However, it is known that many parameters such as temperature, humidity and declination angle are effective in solar radiation coming to on earth. However, so far there have been few studies by producing equations that incorporate too many parameters such as temperature, humidity, altitude and sunshine duration. Therefore, this study, unlike the previous studies, is to develop new models by considering many parameters affecting the solar radiation coming to the earth. In addition, the models developed based on many parameters were compared with the models used in the literature for the most commonly used sunshine duration and which model would yield more realistic results were investigated. This study was conducted in the case of Northern Iraq. The presented work is to make the system designs that connected to solar energy by using the solar radiation based models instead of reliable missing data in the region of Northern Iraq and similar climate.

The main objectives of this study are listed below.

- To examine the applicability of current solar radiation models depending on sunshine duration and other meteorological parameters over the Northern Iraq.

- To compare sunshine duration models with the other meteorological parameters models for global solar radiation prediction models.

- To develop new best general models by utilizing many data such as sunshine duration, maximum temperature, minimum temperature, relative humidity, declination angle for estimating monthly global solar radiation

- To compare the newly developed models with the existing models in the literature and to reveal the best model of these models as a result of statistical evaluation.

- Finally evaluating the applicability of these models for three cities in different latitude, longitude and geographic regions. 
The temperature, humidity, latitude and longitude and declination angle used in this study can be taken from at any meteorological station in the world. Therefore, this study is not only a local study, but can also be used globally. So, the global solar radiation estimation on horizontal surface based on sunshine duration and the other meteorological model of this region has been made by using twenty four empirical models including three new models. Furthermore, the best approach model in the estimation of global solar radiation on the horizontal surface for the Dohuk, Arbil and Sulaimania in the Northern Iraq has been evaluated. Besides, statistical indicators are used to show performance analysis of the models.

\section{Material and Methods}

In this study the average daily global solar radiation data were received from General Directorate of Meteorology and Seismology Forecasting Department and on Ministry of Agriculture and Water Resources in Arbil. Several parameters such as sunshine hours, relative humidity, maximum and minimum temperature were assessed. Sunshine duration can be easily and reliably measured data are widely available. In this work the Sunshine duration sensor model: 217078 have been used as shown in Figure 1a. For measuring global solar radiation, the Pyranometer model QMS101 has been used and it is easily installed on the sensor support arm as shown in Figure 1b. The technical information of Pyranometer model QMS101 is clarified in Table 1. For measuring humidity and temperature, the device model HMP155 were used as shown in Figure 1c.

The data logger model QML201 is a complete AWS logger designed on one printed board

152 differential (20 single ended) analog sensor inputs (these can also be used as digital inputs). Moreover, there are two frequency sensor interfaces, a 16-bit $\mathrm{A} / \mathrm{D}$ converter, $1.7 \mathrm{Mb}$ of secure Flash memory for data logging, as well as excitation power supply for sensors and charger for the internal backup battery. The last mentioned is not needed in the systems where a backup battery with higher capacity is used. The board uses the latest SMD (Surface Mount Device) technology and is conformal coated for improved protection in high humidity. Each sensor input has a varistor 
161

162

163

164

165

166

167

168

169

170

171

172

173

(VDR) protection against induced transients. The serial line connections, that is RS-232 labeled as

COM0 and RS- 485 labeled as COM1, have two level ESD protection circuits with VDRs directly at input pins, as shown in Figure 1d.

Table 1. Technical information of Pyranometer model QMS101.

\begin{tabular}{cc}
\hline Name & Specification \\
\hline Sensitivity & $100 \mu \mathrm{V} / \mathrm{W} / \mathrm{m}^{2}$ (nominal) \\
Spectral range & $0.4 \ldots 1.1$ micron \\
Response time & $<1$ second \\
Range & $2000 \mathrm{~W} / \mathrm{m}^{2}$ \\
Temperature dependence & $+0.15 \% /{ }^{\circ} \mathrm{C}$ \\
Non-stability & $<+2 \%$ per year \\
Non-linearity & $<1 \%$ up to $1000 \mathrm{~W} / \mathrm{m}^{2}$ \\
Operating temperature & $-30 \ldots+70{ }^{\circ} \mathrm{C}$ \\
\hline
\end{tabular}

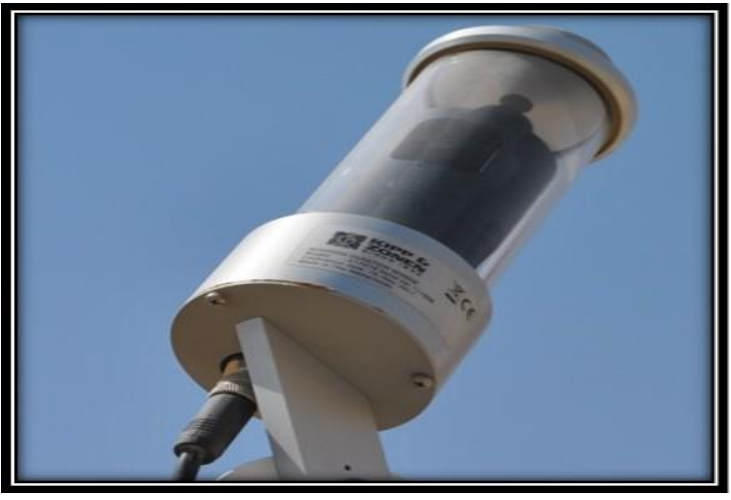

a)

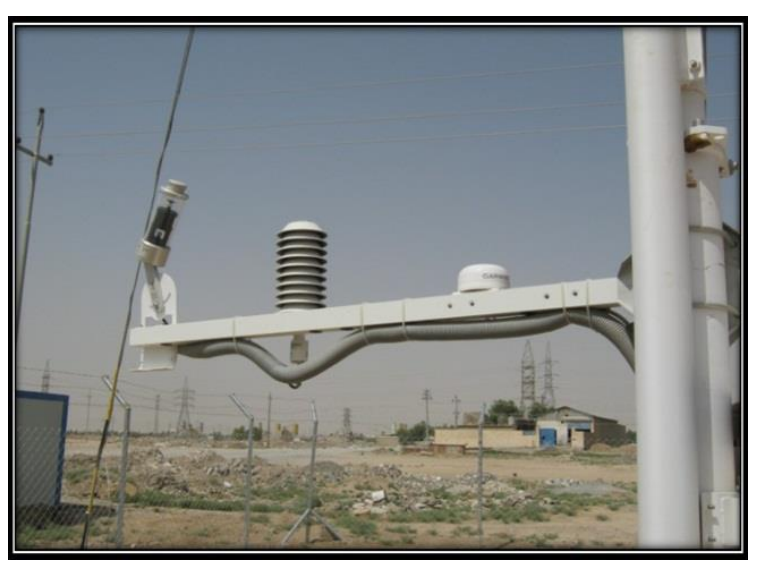

c)

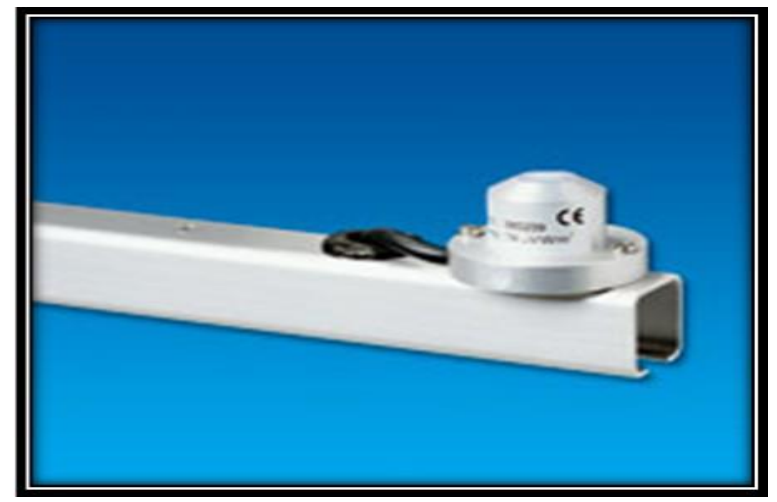

b)

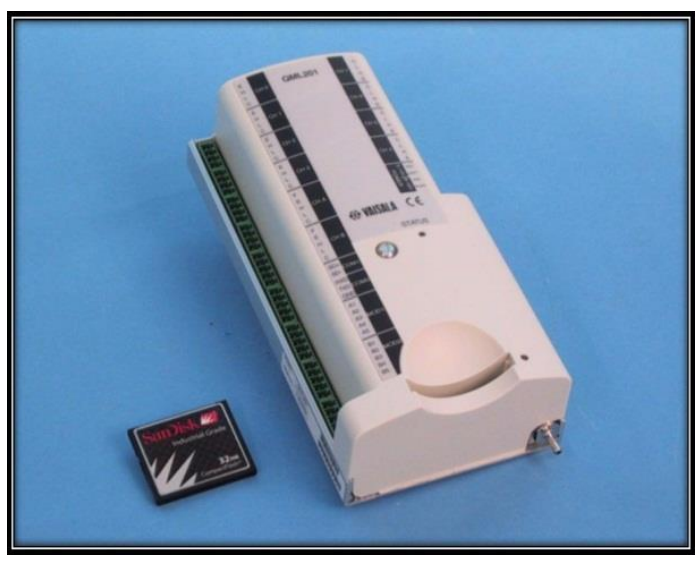

d) 
174 Figure 1. Measurement components of solar radiation, a) Sunshine duration sensors,

175 b) QMS101pyranometer c) installation of Sunshine duration, Pyranometer QMS101 and HMP155

176 device, d) AWS data Logger model QML201

177

\subsection{Studied region and data collection}

179 The common way for estimating the global solar radiation is to set several pyranometers device in a location to record data. In the current research the evaluation of various global solar radiation models for three city of Iraq was investigated. The global solar radiation on a horizontal surface of Arbil, Dohuk, and Sulaimania were estimated using meteorological data. The reason for choosing three different regions in this study is due to different temperature, latitude and longitude values for every region. In addition, the reason for using these different locations is to test the accuracy of the other meteorological parameters models for different regions by comparing the sunshine duration models. The dispersion of the stations used in this study is illustrated in Figure 2. In addition, the geographic information about the latitude, longitude and altitude of each station is given in Table 2.

Table 2. Geographic locations of the studied region

\begin{tabular}{lcccc}
\hline Station & Location & Longitude & Latitude & Altitude \\
\hline Arbil & Central & 43.66 & 36.2688 & 254 \\
Dohuk & North & 43.85 & 36.7314 & 636 \\
Sulaimania & South & 45.96 & 35.2015 & 621 \\
\hline
\end{tabular}

190

191 


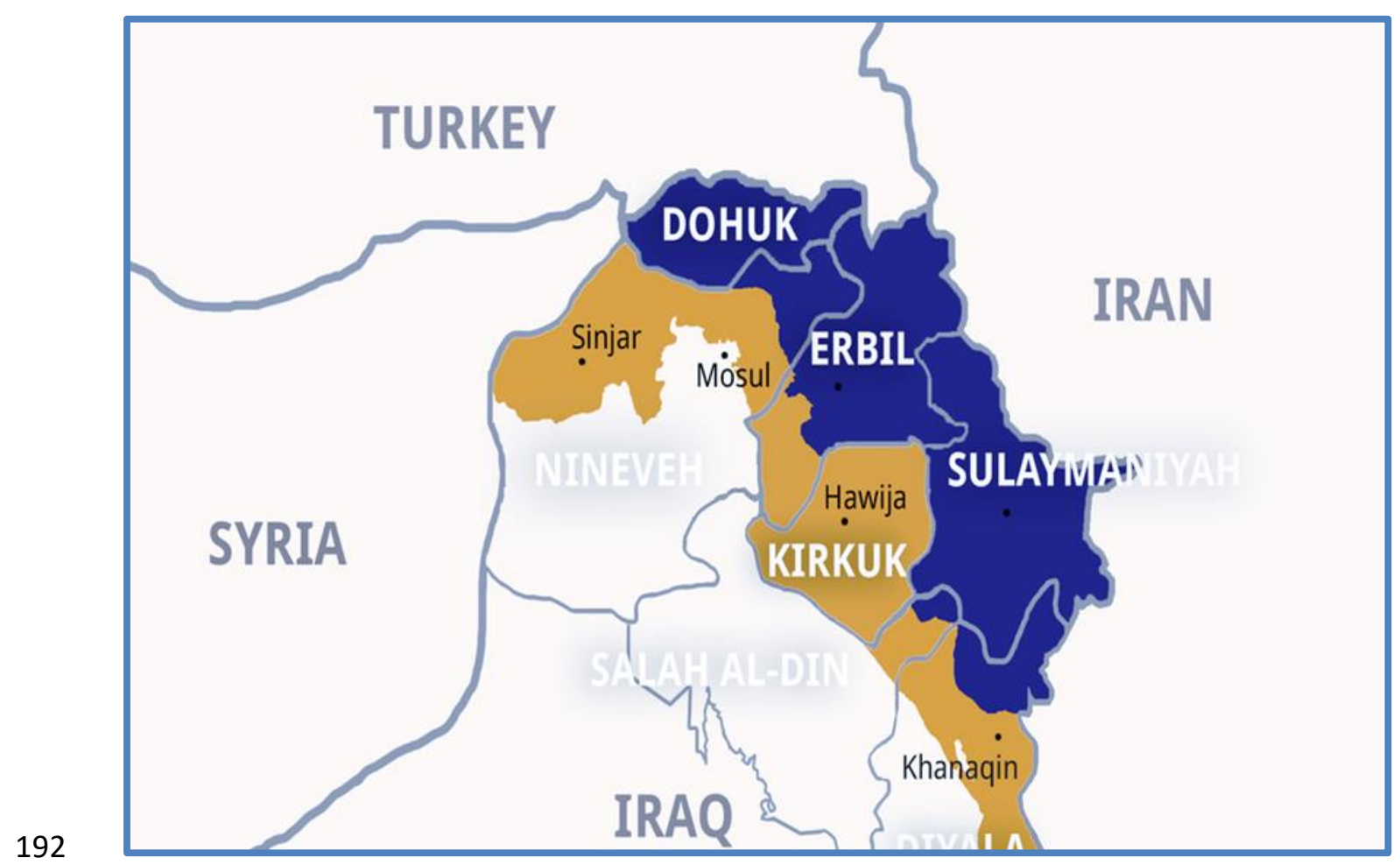

193 Figure 2. The map of the selected locations

Figure 3 shows the monthly averages of meteorological data belonging to the cities of

Arbil, Dohuk and Sulaimania. For each city, different results are obtained when looking at meteorological data such as solar radiation, temperature, humidity.

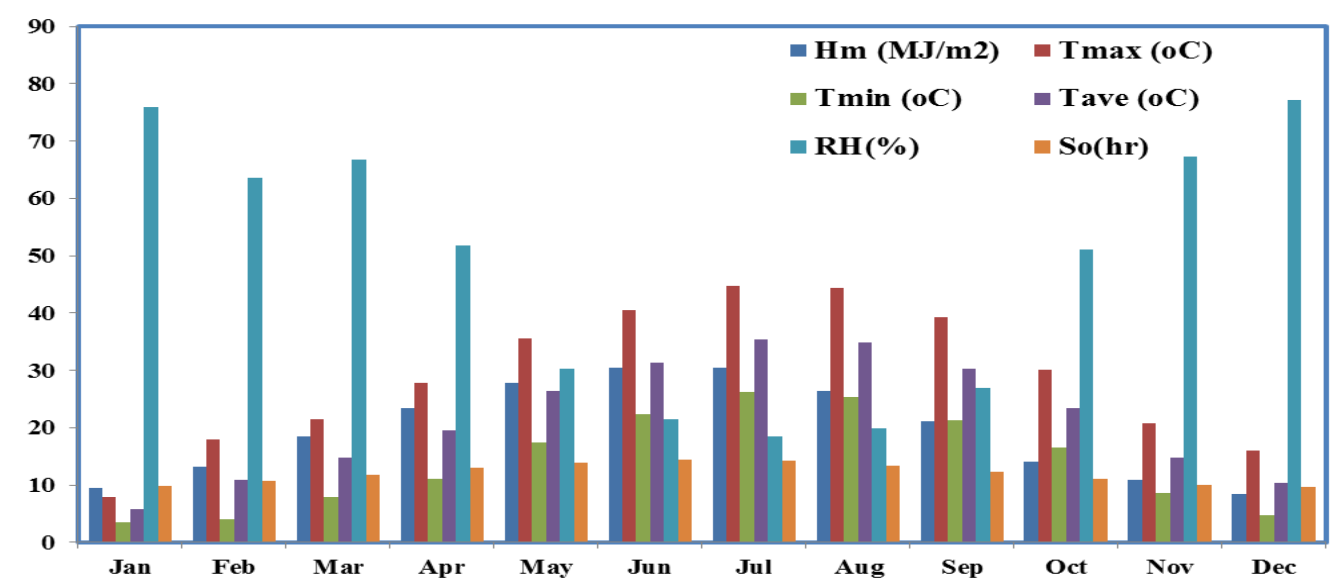




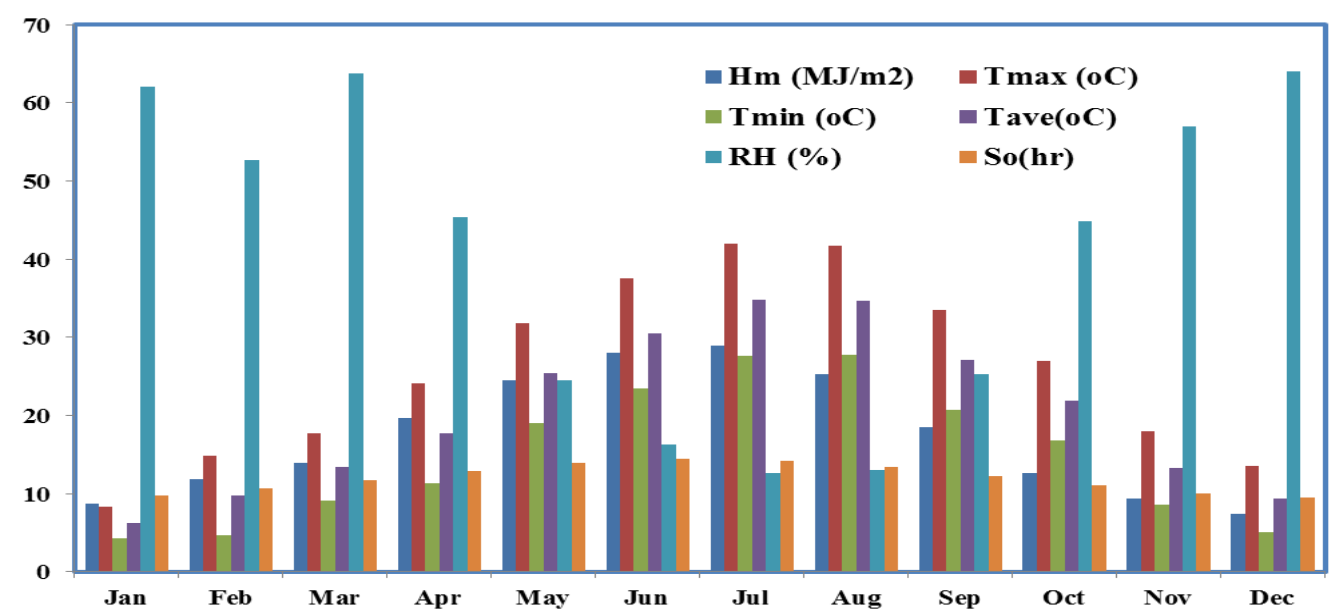

b)

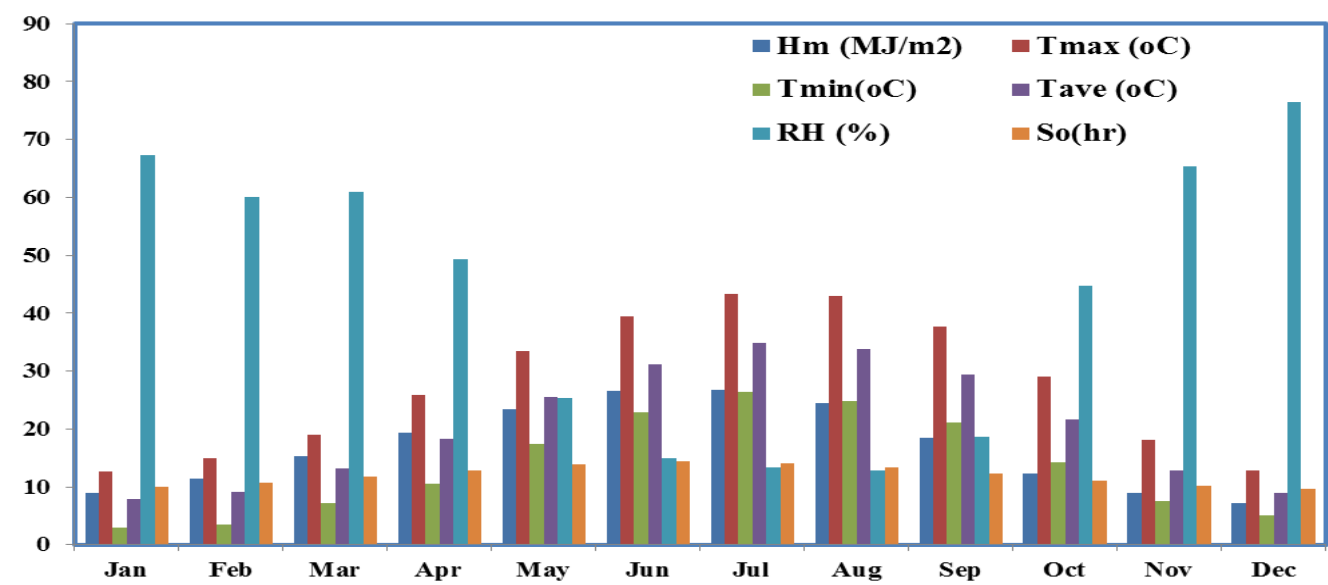

c)

Figure 3. Monthly average meteorological parameters for Arbil (a), Dohuk (b) and Sulaimania (c)

Among the measured results, the highest monthly average solar radiation was measured at Arbil station with a value of $30.4670 \mathrm{MJ} / \mathrm{m}^{2}$. For Dohuk and Sulaimania, these values were measured as $27.9941 \mathrm{MJ} / \mathrm{m}^{2}$ and $26.6617 \mathrm{MJ} / \mathrm{m}^{2}$, respectively. When looking at in terms of the sunshine duration as shown in Fig.3, it seen that there is a difference for the sunshine duration for each of the three cities. As shown in Figure 3, sunshine duration was available for each city. While sunshine duration is reached between 9 and 11 hours for Arbil province, it is seen more between 6 and 8 hours for Dohuk province. At the same time, the sunshine duration in Dohuk province is reaching up to 14 hours. For Sulaimania the sunshine duration reaches up to 12 hours. 

and average values of the ambient air temperature, which is one of the most important meteorological parameters, were also measured. According to the measurement results, the maximum temperature measurement was observed in Arbil with $44.7016{ }^{\circ} \mathrm{C}$. At the same time, the measured maximum temperature values for Dohuk and Sulaimania are above $40{ }^{\circ} \mathrm{C}$. Relative humidity values are one of the parameters that affect the solar radiation coming to the earth. The relative humidity for this region can be as low as $12 \%$ in summer. The relative humidity for the studied area varies from approximately $12 \%$ to $76 \%$ throughout the year. In order to approach the actual measurement results during modeling, the measurement of all the parameters mentioned above and their inclusion in the models become very important.

225

226

227

228

229

231

232

233

234

235

236

237

238

239

240

241

242

243

\subsection{Analysis methods for modeling of global solar radiation}

The simple model used to predict monthly average daily global solar radiation on horizontal surface are based on the Angstrom-Prescott equation,

$$
\frac{\mathrm{H}}{\mathrm{H}_{\circ}}=\mathrm{a}+\mathrm{b}\left(\frac{\mathrm{S}}{\mathrm{S}_{\circ}}\right)
$$

$(\mathrm{H})$, is the monthly average daily global radiation on horizontal surface $\left(\mathrm{MJ} / \mathrm{m}^{2}\right.$ day).

$\left(\mathrm{H}_{\circ}\right)$, is the monthly average daily extraterrestrial irradiation $\left(\mathrm{MJ} / \mathrm{m}^{2}\right.$ day), should be calculated from the following equation (Duffie 2013),

$$
\mathrm{H} \circ=\frac{24}{\pi} \mathrm{I}_{\mathrm{sc}}\left[1+0.033 \cos \left(\frac{360}{365} \mathrm{n}\right)\right]\left[\sin \mathrm{w}_{\mathrm{s}} \cos \varphi \cos \delta+\mathrm{w}_{\mathrm{s}} \sin \varphi \sin \delta\right]
$$

Where $\left(\mathrm{I}_{\mathrm{sc}}\right)$ is the solar constant, $(\varphi)$ is the latitude, $(\delta)$ is the solar declination, $\left(\omega_{\mathrm{s}}\right)$ is the mean sunrise hour angle, $(S)$ is the monthly average daily hours of bright sunshine and (So) is the monthly average daily length where calculated by following equation (Duffie 2013),

$$
\delta=23.45 \sin \left[\left(\frac{360}{365}\right)(384+n)\right]
$$

$\mathrm{w}_{\mathrm{S}}=\cos ^{-1} \tan \varphi \cos \delta$ 
$245 \quad S_{\circ}=\frac{2}{15} \mathrm{w}_{\mathrm{S}}$

\subsection{Selection of Empirical Model}

Two different types of empirical models were used in this study. One of them is models that only depend on the sunshine duration. Another is the models which depend on other meteorological parameters, including various meteorological parameters. In this study, 24 models were evaluated.

Among these models, the first 11 models are models that only depend on the sunshine duration.

These models are often used in the literature and the accuracy rates are high models. Examined and. developed models for this work are presented in Table 3.

Table 3. Models used and newly developed model

\begin{tabular}{|c|c|c|c|}
\hline No & Source & Model Type & Equation \\
\hline $\mathbf{H}_{1}$ & $\begin{array}{l}\text { Angstrom-mott [1924; } \\
\text { 1940] }\end{array}$ & Linear & $\mathrm{H} / \mathrm{H}_{\circ}=\mathrm{a}+\mathrm{b}\left(\mathrm{S} / \mathrm{S}_{\circ}\right)$ \\
\hline $\mathbf{H}_{2}$ & Ogelman [1984] & Quadratic & $\mathrm{H} / \mathrm{H}_{\circ}=\mathrm{a}+\mathrm{b}\left(\mathrm{S} / \mathrm{S}_{\circ}\right)+\mathrm{c}\left(\mathrm{S} / \mathrm{S}_{\circ}\right)^{2}$ \\
\hline $\mathbf{H}_{3}$ & Samuel [1991] & Qubic & $\begin{array}{c}\mathrm{H} / \mathrm{H}_{\circ}=\mathrm{a}+\mathrm{b}\left(\mathrm{S} / \mathrm{S}_{\circ}\right)+\mathrm{c}\left(\mathrm{S} / \mathrm{S}_{\circ}\right)^{2} \\
+\mathrm{d}\left(\mathrm{S} / \mathrm{S}_{\circ}\right)^{3}\end{array}$ \\
\hline $\mathbf{H}_{4}$ & $\begin{array}{l}\text { Ampratwum and Dorvlo } \\
\text { [1999] }\end{array}$ & Linear & $\mathrm{H} / \mathrm{H}_{\circ}=\mathrm{a}+\mathrm{b} \log \left(\mathrm{S} / \mathrm{S}_{\circ}\right)$ \\
\hline $\mathbf{H}_{5}$ & Sen [2007] & Power & $\mathrm{H} / \mathrm{H}_{\circ}=\mathrm{a}+\mathrm{b}\left(\mathrm{S} / \mathrm{S}_{\circ}\right)^{\mathrm{c}}$ \\
\hline $\mathbf{H}_{6}$ & Bakirci [2009] & Power & $\mathrm{H} / \mathrm{H}_{\circ}=\mathrm{a}\left(\mathrm{S} / \mathrm{S}_{\circ}\right)^{\mathrm{b}}$ \\
\hline $\mathbf{H}_{7}$ & Elagib \& Mansell, [2000] & Exponential & $\mathrm{H} / \mathrm{H}_{\circ}=\mathrm{a} \exp \left[\mathrm{b}\left(\mathrm{S} / \mathrm{S}_{\circ}\right)\right]$ \\
\hline $\mathbf{H}_{8}$ & $\begin{array}{l}\text { Almorox \& Hontoria, } \\
\text { [2004] }\end{array}$ & Exponential & $\mathrm{H} / \mathrm{H}_{\circ}=\mathrm{a}+\mathrm{b} \exp \left(\mathrm{S} / \mathrm{S}_{\circ}\right)$ \\
\hline $\mathbf{H}_{9}$ & Bakirci [2009] & $\begin{array}{l}\text { Linear- } \\
\text { Exponential }\end{array}$ & $\mathrm{H} / \mathrm{H}_{\circ}=\mathrm{a}+\mathrm{b}\left(\mathrm{S} / \mathrm{S}_{\circ}\right)+\mathrm{c} \exp \left(\mathrm{S} / \mathrm{S}_{\circ}\right)$ \\
\hline $\mathbf{H}_{10}$ & Newland [1988] & $\begin{array}{l}\text { Linear- } \\
\text { Logarithmic }\end{array}$ & $\mathrm{H} / \mathrm{H}_{\circ}=\mathrm{a}+\mathrm{b}\left(\mathrm{S} / \mathrm{S}_{\circ}\right)+\mathrm{c} \log \left(\mathrm{S} / \mathrm{S}_{\circ}\right)$ \\
\hline $\mathbf{H}_{11}$ & Togrul and Onat [1999] & Linear & $\mathrm{H}=\mathrm{a}+\mathrm{bH} \mathrm{H}_{\circ}+\mathrm{c}\left(\mathrm{S} / \mathrm{S}_{\circ}\right)$ \\
\hline $\mathbf{H}_{12}$ & El-Sebaii et al., [2009] & Linear & $\mathrm{H} / \mathrm{H}_{\circ}=\mathrm{a}+\mathrm{b}\left(\mathrm{S} / \mathrm{S}_{\circ}\right)+\mathrm{cT}$ \\
\hline
\end{tabular}




\begin{tabular}{|c|c|c|c|}
\hline$\overline{H_{13}}$ & Togrul \& Onat, [1999] & Trigonometric & $\mathrm{H}=\mathrm{a}+\mathrm{b} \sin (\delta)$ \\
\hline $\mathbf{H}_{14}$ & Togrul \& Onat, [1999] & $\begin{array}{l}\text { Linear- } \\
\text { Trigonometric }\end{array}$ & $\mathrm{H}=\mathrm{a}+\mathrm{b}\left(\mathrm{S} / \mathrm{S}_{\circ}\right)+\mathrm{c} \sin (\delta)$ \\
\hline $\mathbf{H}_{15}$ & $\begin{array}{l}\text { Glower \& McCulloch, } \\
\text { [1958] }\end{array}$ & Trigonometric & $\mathrm{H} / \mathrm{H}_{\circ}=\mathrm{a} \cos \varphi+\mathrm{b}\left(\mathrm{S} / \mathrm{S}_{\circ}\right)$ \\
\hline $\mathbf{H}_{16}$ & $\begin{array}{l}\text { Togrul \& Onat, Model } \\
\text { [1999] }\end{array}$ & $\begin{array}{l}\text { Linear- } \\
\text { Trigonometric }\end{array}$ & $\mathrm{H}=\mathrm{a}+\mathrm{b}\left(\mathrm{S} / \mathrm{S}_{\circ}\right)+\mathrm{c} \sin (\delta)+\mathrm{dT}$ \\
\hline $\mathbf{H}_{17}$ & New Model & $\begin{array}{l}\text { Linear- } \\
\text { Trigonometric }\end{array}$ & $\begin{array}{c}\mathrm{H} / \mathrm{H}_{\circ}=\mathrm{a}+\mathrm{b} \ln \left(\mathrm{T}_{\min } / \mathrm{T}_{\max }\right) \\
+\mathrm{c} \sin (\delta)\end{array}$ \\
\hline $\mathbf{H}_{18}$ & Chen et al., [2004] & $\begin{array}{l}\text { Logarithmic- } \\
\text { Power }\end{array}$ & $\begin{array}{c}\mathrm{H} / \mathrm{H}_{\circ}=\mathrm{a} \ln \left(\mathrm{T}_{\max }-\mathrm{T}_{\min }\right)+\mathrm{b}\left(\mathrm{S} / \mathrm{S}_{\circ}\right)^{\mathrm{c}} \\
+\mathrm{d}\end{array}$ \\
\hline $\mathbf{H}_{19}$ & Annandale et al., [2002] & Power & $\begin{aligned} \mathrm{H} / \mathrm{H} \circ=\mathrm{a}(1+ & 2.7 \\
& \left.* 10^{-5} \mathrm{Z}\right)\left(\mathrm{T}_{\max -} \mathrm{T}_{\min }\right)^{0.5}\end{aligned}$ \\
\hline $\mathbf{H}_{20}$ & $\begin{array}{l}\text { Swartman and Ogunlade, } \\
\text { [1967] }\end{array}$ & Linear & $\mathrm{H} / \mathrm{H}_{\circ}=\mathrm{a}+\mathrm{b}\left(\mathrm{S} / \mathrm{S}_{\circ}\right)+\mathrm{cRH}$ \\
\hline $\mathbf{H}_{21}$ & El-Sebaii et al., [2009] & Linear & $\mathrm{H} / \mathrm{H} \circ=\mathrm{a}+\mathrm{bT}+\mathrm{cRH}$ \\
\hline $\mathbf{H}_{22}$ & New Model & Linear-Power & $\begin{aligned} \mathrm{H} / \mathrm{H}_{\circ}=\mathrm{a}+\mathrm{b} & \left(\mathrm{S} / \mathrm{S}_{\circ}\right) \\
& +\mathrm{c}\left(\mathrm{T}_{\min } / \mathrm{T}_{\max }\right)^{-1} \\
& +\mathrm{dRH}\end{aligned}$ \\
\hline $\mathbf{H}_{23}$ & Abdalla, [1994] & Linear & $\mathrm{H} / \mathrm{H}_{\circ}=\mathrm{a}+\mathrm{b}\left(\mathrm{S} / \mathrm{S}_{\circ}\right)+\mathrm{cT}+\mathrm{dRH}$ \\
\hline $\mathbf{H}_{24}$ & New Model & $\begin{array}{l}\text { Linear- } \\
\text { Logarithmic }\end{array}$ & $\begin{array}{c}\mathrm{H} / \mathrm{H}_{\circ}=\mathrm{a}+\mathrm{b} \ln \Delta \mathrm{T}+\mathrm{c}\left(\mathrm{T}_{\min } / \mathrm{T}_{\max }\right) \\
+\mathrm{dRH}\end{array}$ \\
\hline
\end{tabular}
developed models are included in these type models. In addition, different regression equations such as linear, exponential, cubic, quadratic and exponential have been used to increase accuracy of these models.

261 The selected twenty one models are the ones accepted in the literature and applied to the regions with different climatic conditions.

\subsection{Statistical Performance Validation}


For evaluating the models different statistical indicators such as the mean bias error (MBE), mean percentage error (MPE), root mean square error (RMSE), coefficient of determination $\left(\mathrm{R}^{2}\right)$ measures the conformity of the regression model, were used and these were presented in the following equations:

$$
\begin{aligned}
& \operatorname{MPE}(\%)=\frac{1}{\mathrm{X}} \sum_{\mathrm{i}=1}^{\mathrm{X}}\left(\frac{H_{c}-H_{m}}{H_{m}}\right) \times 100 \\
& \operatorname{MBE}=\frac{1}{X} \sum_{i=1}^{X}\left(H_{c}-H_{m}\right)
\end{aligned}
$$

$$
\operatorname{RMSE}=\sqrt{\frac{1}{\mathrm{x}} \sum_{\mathrm{i}=1}^{\mathrm{X}}\left(\mathrm{H}_{\mathrm{c}}-\mathrm{H}_{\mathrm{m}}\right)^{2}}
$$

$$
\mathrm{R}^{2}=\frac{\sum_{i=1}^{X}\left(\mathrm{H}_{\mathrm{c}}-\mathrm{H}_{\mathrm{c} \mathrm{avg}}\right) \cdot\left(\mathrm{H}_{\mathrm{m}}-\mathrm{H}_{\mathrm{m} \mathrm{avg}}\right)}{\sqrt{\left[\frac{1}{X} \sum_{i=1}^{X}\left(\mathrm{H}_{\mathrm{c}}-\mathrm{H}_{\mathrm{c} \mathrm{avg}}\right)^{2}\right] \cdot\left[\frac{1}{X} \sum_{i=1}^{X}\left(\mathrm{H}_{\mathrm{m}}-\mathrm{H}_{\mathrm{m} \mathrm{avg}}\right)^{2}\right]}}
$$

Where $\mathrm{H}_{c}$ and $\mathrm{H}_{\mathrm{m}}$ represents the calculated and the measured of solar radiation, respectively, and $x$ is the total number of observations. The value of $H_{c}$ avg and $H_{m}$ avg are the average of the calculated and measured solar radiation, respectively.

\section{Results and Discussion}

The constant regression coefficients of the equations used in the application of solar radiation prediction models in any region take different values for each studied region. Therefore, using the correct constant regression coefficients in the application of the equations gives closer results to the actual values. Although there are many similar studies in the literature, the results of these studies may vary for each region. Therefore, regression coefficients of the models taken in the literature are very important. In this study, sunshine duration models and the other meteorological parameter models regression coefficients that are a, b, c and d shown in Table 4 and Table 5 were developed for 24 models and applied to different regions. These models were widely utilized in the literature, and regression coefficients for every models were found for each province in the studied 
region. It was observed that the regression coefficients founded is different for each model and every cities. This difference is due to various factors such as climatic conditions, geographical conditions, latitude, longitude and altitude. Statistical methods such as MPE, RMSE, MBE, and $\mathrm{R}^{2}$ were used for the correctness of the models.

Various statistical parameters are used in order determine the accuracy of the solar radiation models. Although many statistical error values have been calculated in most of the previous studies, the performance of the models can be ranked according to $\mathrm{R}^{2}$ indicator (Hassan et al. 2016; El Mghouchi 2016; Besharat 2013). The $\mathrm{R}^{2}$ value is the one of important statistical indicators. Table 4 also gives $\mathrm{R}^{2}$ values for each city. According to this table, eleven sunshine duration models were evaluated for three different cities based on this parameter. As a result of the evaluations, the each models provide different performance value for each city. For Arbil province, H11 show the best performance with a value of 0.9903 . Besides this, the models of H5 and H3 for the best $\mathrm{R}^{2}$ values of Dohuk and Sulaimania show best performance with 0.9853 and 0.9823 respectively. This study consists of two categories. The first one is the calculations based on the sunshine duration and the another one based on the other meteorological parameters. According to the other meteorological parameters, the statistical values of the models and the constant coefficients of the equations are given in Table 5. A total of thirteen model based on the other meteorological parameters were used for each city. In these models, three new models were developed and applied to three different locations. The monthly global solar radiation values for every models and cities are compared based on statistical parameters. It is observed that there is a difference between two type models. At the same time, the newly developed models that is depend of the other meteorological parameters show a better performance than the models depending on the sunshine duration. Furthermore, the models giving the best results are found for every cities. Detailed explanations of the work done for each city were explained in the following subheadings. Table 4. Results of sunshine duration models with the statistical indicators and correlation coefficient 


\begin{tabular}{|c|c|c|c|c|c|c|c|c|c|c|}
\hline Station & Models & $\mathbf{R}^{2}$ & MBE & RMSE & MPE & $\mathbf{a}$ & b & c & d & Rank \\
\hline \multirow{11}{*}{ Arbil } & $\mathbf{H}_{1}$ & 0.9654 & -0.3377 & 1.8079 & -0.6341 & 0.1997 & 0.6431 & - & - & 9 \\
\hline & $\mathbf{H}_{2}$ & 0.9767 & -0.2718 & 1.528 & -0.5007 & -1.0201 & 4.2329 & -2.6018 & - & 5 \\
\hline & $\mathbf{H}_{3}$ & 0.9769 & -0.2254 & 1.4264 & -0.5349 & 10.080 & -45.61 & 71.116 & -35.91 & 4 \\
\hline & $\mathbf{H}_{4}$ & 0.9874 & -0.5909 & 1.9739 & -0.5951 & 0.7112 & 0.4481 & - & - & 2 \\
\hline & $\mathbf{H}_{5}$ & 0.9701 & -0.3311 & 1.6388 & -0.0533 & 0.8261 & -0.0655 & -2.6018 & - & 7 \\
\hline & $\mathrm{H}_{6}$ & 0.9637 & -0.3729 & 1.818 & -0.293 & 0.8411 & 0.7245 & - & - & 10 \\
\hline & $\mathbf{H}_{7}$ & 0.9607 & -0.3927 & 1.8849 & -0.3171 & 0.3122 & 1.0386 & - & - & 11 \\
\hline & $\mathrm{H}_{8}$ & 0.9668 & -0.3374 & 1.8325 & -0.8611 & 0.0448 & 0.2995 & - & - & 8 \\
\hline & H9 & 0.9772 & -0.2775 & 1.5208 & -0.4982 & 1.8509 & 5.9538 & -2.6567 & - & 3 \\
\hline & $\mathbf{H}_{10}$ & 0.9734 & -0.3446 & 1.5346 & 0.3703 & 4.5573 & -3.9330 & 7.3225 & - & 6 \\
\hline & $\mathrm{H}_{11}$ & 0.9903 & -0.0428 & 0.7767 & 0.6737 & -7.3271 & 0.8605 & 1.9753 & - & 1 \\
\hline \multirow{11}{*}{ Dohuk } & $\mathbf{H}_{1}$ & 0.9837 & -0.1226 & 1.0359 & -0.2612 & 0.1332 & 0.6263 & - & - & 8 \\
\hline & $\mathbf{H}_{2}$ & 0.9847 & -0.1129 & 1.0076 & -0.2437 & -0.1269 & 1.3691 & -0.5157 & - & 3 \\
\hline & $\mathbf{H}_{3}$ & 0.9850 & -0.1062 & 1.0029 & -0.2882 & -2.4496 & 11.583 & -15.289 & 7.0219 & 2 \\
\hline & $\mathbf{H}_{4}$ & 0.9841 & 0.1512 & 1.0152 & -0.3541 & 0.7393 & 1.0521 & - & - & 7 \\
\hline & $\mathbf{H}_{5}$ & 0.9853 & 0.0674 & 0.9701 & -1.3529 & 1.4685 & -0.7255 & -0.5157 & - & 1 \\
\hline & $\mathrm{H}_{6}$ & 0.9844 & 0.3393 & 1.0201 & -3.0226 & 0.7701 & 0.7532 & - & - & 4 \\
\hline & $\mathbf{H}_{7}$ & 0.9827 & -0.1496 & 1.0686 & -0.1368 & 0.2658 & 1.0803 & - & - & 9 \\
\hline & $\mathrm{H}_{8}$ & 0.9825 & -0.1526 & 1.0674 & -0.0674 & -0.053 & 0.3075 & - & - & 10 \\
\hline & $\mathrm{H}_{9}$ & 0.9843 & -0.1508 & 1.009 & 0.1386 & 0.5123 & 2.0282 & -0.6717 & - & 5 \\
\hline & $\mathbf{H}_{10}$ & 0.9843 & -0.1501 & 1.0068 & 0.1442 & 1.0481 & -0.3207 & 1.5777 & - & 6 \\
\hline & $\mathrm{H}_{11}$ & 0.9781 & -0.1199 & 1.1218 & 1.8732 & -12.759 & 0.6683 & 14.877 & - & 11 \\
\hline \multirow{11}{*}{ Sulaimania } & $\mathrm{H}_{1}$ & 0.9799 & -0.1469 & 1.1394 & -0.4011 & 0.1987 & 0.5038 & - & - & 2 \\
\hline & $\mathbf{H}_{2}$ & 0.9787 & -0.1518 & 1.1471 & -0.3952 & 0.2519 & 0.3418 & 0.1188 & - & 5 \\
\hline & $\mathbf{H}_{3}$ & 0.9823 & -0.1291 & 1.0229 & -0.3389 & 1.8074 & -7.0923 & 11.6310 & -5.7864 & 1 \\
\hline & $\mathbf{H}_{4}$ & 0.9786 & -0.1897 & 1.1526 & 0.0142 & 0.6770 & 0.7843 & - & - & 6 \\
\hline & $\mathbf{H}_{5}$ & 0.9776 & -0.1901 & 1.1494 & 0.0252 & -2.3455 & 3.0258 & 0.1188 & - & 9 \\
\hline & $\mathbf{H}_{6}$ & 0.9798 & -0.192 & 1.1604 & 1.1604 & 0.6864 & 0.6096 & - & - & 3 \\
\hline & $\mathbf{H}_{7}$ & 0.9782 & -0.1885 & 1.1692 & -0.2159 & 0.2854 & 0.9279 & - & - & 7 \\
\hline & $\mathbf{H}_{8}$ & 0.9787 & -0.2032 & 1.1719 & 0.0312 & 0.0184 & 0.2616 & - & - & 4 \\
\hline & $\mathbf{H}_{9}$ & 0.9778 & -0.1979 & 1.1536 & 0.0549 & 0.1346 & 0.3686 & 0.0772 & - & 8 \\
\hline & $\mathbf{H}_{10}$ & 0.9775 & -0.2006 & 1.1572 & 0.0606 & -0.0235 & 0.7408 & -0.3339 & - & 10 \\
\hline & $\mathbf{H}_{11}$ & 0.9765 & -0.1265 & 1.0777 & 1.8627 & -9.1202 & 0.7135 & 6.6346 & - & 11 \\
\hline
\end{tabular}

323 Table 5. Results of the other meteorological parameters models with the statistical 324 indicators and correlation coefficient 


\begin{tabular}{|c|c|c|c|c|c|c|c|c|c|c|}
\hline Station & Models & $\mathbf{R}^{2}$ & MBE & RMSE & MPE & $\mathbf{a}$ & b & c & d & Rank \\
\hline \multirow{13}{*}{ Arbil } & $\mathbf{H}_{12}$ & 0.9855 & -0.1653 & 1.0261 & -0.0676 & 0.4336 & 0.1018 & 0.0062 & & 9 \\
\hline & $\mathbf{H}_{13}$ & 0.9960 & -0.0011 & 0.4994 & -0.0056 & 19.499 & 28.173 & --- & --- & 3 \\
\hline & $\mathbf{H}_{14}$ & 0.9970 & -0.0339 & 0.4345 & 0.4755 & 16.457 & 4.4153 & 27.5018 & & 2 \\
\hline & $\mathbf{H}_{15}$ & 0.9669 & -0.5763 & 1.9092 & 0.5506 & 0.260 & 0.6173 & --- & --- & 11 \\
\hline & $\mathbf{H}_{16}$ & 0.9971 & -0.0378 & 0.4325 & 0.4974 & 16.590 & 3.6554 & 27.126 & 0.0178 & 1 \\
\hline & $\mathbf{H}_{17}$ & 0.9958 & 0.0217 & 0.5141 & -0.3082 & 0.6579 & 0.0227 & 0.2378 & --- & 4 \\
\hline & $\mathbf{H}_{18}$ & 0.9535 & -0.5669 & 1.9729 & 5.4061 & 0.3848 & 0.0049 & -2.6018 & -0.4212 & 13 \\
\hline & $\mathrm{H}_{19}$ & 0.9760 & -0.0434 & 1.2432 & 0.8962 & 0.1656 & --- & --- & --- & 10 \\
\hline & $\mathbf{H}_{20}$ & 0.9896 & -0.0797 & 0.8510 & -0.4140 & 0.7696 & 0.0176 & -0.0030 & --- & 8 \\
\hline & $\mathbf{H}_{21}$ & 0.9897 & -0.0525 & 0.8445 & -0.6164 & 0.9044 & -0.0029 & -0.0043 & --- & 6 \\
\hline & $\mathbf{H}_{22}$ & 0.9897 & -0.0518 & 0.8440 & -0.5926 & 0.7703 & 0.0157 & 0.0007 & -0.003 & 5 \\
\hline & $\mathbf{H}_{23}$ & 0.9897 & -0.0552 & 0.8467 & -0.6140 & 0.8916 & 0.0154 & -0.0029 & -0.0042 & 7 \\
\hline & $\mathbf{H}_{24}$ & 0.9636 & -0.4838 & 1.6979 & 4.5104 & -0.2682 & 0.326 & 0.0610 & -0.0001 & 12 \\
\hline \multirow{13}{*}{ Dohuk } & $\mathrm{H}_{12}$ & 0.9903 & -0.1260 & 0.7566 & 0.6315 & 0.2556 & 0.30218 & 0.0049 & --- & 6 \\
\hline & $\mathbf{H}_{13}$ & 0.9703 & -0.0791 & 1.2922 & 0.9739 & 17.301 & 26.6784 & --- & --- & 12 \\
\hline & $\mathbf{H}_{14}$ & 0.9886 & -0.0937 & 0.8122 & 1.4675 & 8.0062 & 13.3103 & 22.5046 & --- & 8 \\
\hline & $\mathbf{H}_{15}$ & 0.9831 & -0.2344 & 1.0936 & 0.2415 & 0.1488 & 0.6386 & --- & --- & 9 \\
\hline & $\mathrm{H}_{16}$ & 0.9892 & -0.1213 & 0.8021 & 1.7678 & 8.9319 & 9.36078 & 21.2383 & 0.0885 & 7 \\
\hline & $\mathbf{H}_{17}$ & 0.9731 & -0.0223 & 1.2099 & -0.0069 & 0.5983 & 0.04705 & 0.23405 & --- & 10 \\
\hline & $\mathrm{H}_{18}$ & 0.9717 & -0.3524 & 1.3537 & 3.5443 & 0.2432 & -0.3174 & -0.5157 & 0.3674 & 11 \\
\hline & $\mathbf{H}_{19}$ & 0.9668 & -0.2188 & 1.3894 & 1.0523 & 0.1688 & --- & --- & --- & 13 \\
\hline & $\mathbf{H}_{20}$ & 0.9941 & -0.0710 & 0.5802 & 0.3985 & 0.6331 & 0.10588 & -0.0035 & --- & 2 \\
\hline & $\mathbf{H}_{21}$ & 0.9936 & -0.0616 & 0.6046 & 0.3538 & 0.7468 & -0.0004 & -0.0043 & --- & 4 \\
\hline & $\mathbf{H}_{22}$ & 0.9942 & -0.0789 & 0.5752 & 0.4788 & 0.6512 & 0.07032 & 0.01171 & -0.0039 & 1 \\
\hline & $\mathbf{H}_{23}$ & 0.9940 & -0.0700 & 0.5809 & 0.3862 & 0.641 & 0.10472 & -0.0002 & -0.0036 & 3 \\
\hline & $\mathbf{H}_{24}$ & 0.9924 & -0.1240 & 0.6639 & 1.1364 & 0.6526 & 0.04702 & -0.0743 & -0.004 & 5 \\
\hline \multirow{13}{*}{ Sulaimania } & $\mathbf{H}_{12}$ & 0.9894 & -0.1579 & 0.7403 & 0.6033 & 0.3444 & 0.0955 & 0.0064 & -- & 7 \\
\hline & $\mathbf{H}_{13}$ & 0.9813 & -0.0855 & 0.9534 & 0.8748 & 16.8280 & 24.8414 & --- & --- & 10 \\
\hline & $\mathbf{H}_{14}$ & 0.9881 & -0.0982 & 0.7693 & 1.3869 & 11.8768 & 7.1699 & 22.3475 & --- & 8 \\
\hline & $\mathbf{H}_{15}$ & 0.9771 & -0.7765 & 1.4540 & 3.6815 & 0.2011 & 0.5223 & --- & --- & 13 \\
\hline & $\mathbf{H}_{16}$ & 0.9903 & -0.1131 & 0.7032 & 1.3589 & 13.1573 & 1.7826 & 20.7819 & 0.1177 & 6 \\
\hline & $\mathbf{H}_{17}$ & 0.9830 & -0.1032 & 0.9174 & 0.9714 & 0.5860 & 0.0546 & 0.2254 & --- & 9 \\
\hline & $\mathbf{H}_{18}$ & 0.9796 & -0.1585 & 1.0682 & 0.2747 & 0.1646 & 1.2628 & 0.1188 & -1.0899 & 11 \\
\hline & $\mathbf{H}_{19}$ & 0.9781 & 0.4324 & 1.1176 & -3.3091 & 0.1499 & --- & --- & --- & 12 \\
\hline & $\mathbf{H}_{20}$ & 0.9907 & 0.0944 & 0.6703 & -0.8517 & 0.7512 & -0.0729 & -0.0036 & --- & 5 \\
\hline & $\mathbf{H}_{21}$ & 0.9908 & -0.1076 & 0.6729 & 0.4008 & 0.6468 & 0.0008 & -0.0028 & --- & 4 \\
\hline & $\mathbf{H}_{22}$ & 0.9909 & -0.0725 & 0.6671 & 0.1150 & 0.7716 & -0.1167 & 0.0093 & -0.0040 & 2 \\
\hline & $\mathbf{H}_{23}$ & 0.9908 & -0.1004 & 0.6718 & 0.3696 & 0.7196 & -0.0689 & 0.0006 & -0.0033 & 3 \\
\hline & $\mathbf{H}_{24}$ & 0.9910 & -0.0880 & 0.6717 & 0.2141 & 0.7538 & -0.0112 & -0.0653 & -0.0036 & 1 \\
\hline
\end{tabular}



parameter models was given in Table 5 according to the $\mathrm{R}^{2}$ values. One of the main aims of this study is to compare of the models based on the sunshine duration and other meteorological parameters with each other. In this study, it was applied in different places to reveal the difference between two different type models more clearly. Table 6 shows the first three models for different cities, which show the best results, depending on the sunshine duration and other meteorological parameters among twenty four models used in this study. When looking at this table, it is seen that the models depending on other meteorological parameters generally perform much better than the models depending on the sunshine duration. While the $\mathrm{R}^{2}$ value of the best models depending on the sunshine duration ranged from 0.97 to 0.99 , the $\mathrm{R}^{2}$ values of the best models of other meteorological parameters are above 0.99. For Arbil, the H11 model shows the best performance in Sunshine duration models with 0.9903 . But, for the same city, the best performance in the other meteorological parameters is indicated by the H16 model with a value of 0.9971 . While the H5 model shows the best performance according to the sunshine duration for Dohuk province with 0.9853, the H22 model show the best performance with 0.9942 value acoording to the other meteorological parameters. In addition, the newly developed H22 and H24 model has the best performance for Dohuk and Sulaimania respectively in the all models. best performance with 0.9823 values. However, the newly developed H24 model based on the other meteorological parameters shows the best performance among all of model with the value of 0.9910 for Sulaimania. 
Table 6. Comparison of the best of sunshine duration models and the other meteorological parameter models

\begin{tabular}{|c|c|c|c|c|c|c|}
\hline \multirow[t]{2}{*}{ City } & \multirow[t]{2}{*}{ Rank } & \multicolumn{2}{|c|}{$\begin{array}{c}\text { Sunshine } \\
\text { Duration Models }\end{array}$} & \multicolumn{2}{|c|}{$\begin{array}{c}\text { Meteorological } \\
\text { Parameter Models }\end{array}$} & \multirow[t]{2}{*}{$\begin{array}{l}\text { Differences in } \\
\text { RMSE }\end{array}$} \\
\hline & & Model & $\mathrm{R}^{2}$ & Model & $\mathrm{R}^{2}$ & \\
\hline \multirow{3}{*}{ Arbil } & 1 & $\overline{H_{11}}$ & 0.9903 & $\overline{H_{16}}$ & 0.9971 & -0.3442 \\
\hline & 2 & $\mathbf{H}_{4}$ & 0.9874 & $\mathbf{H}_{14}$ & 0.9970 & -1.5394 \\
\hline & 3 & $\mathbf{H}_{9}$ & 0.9772 & $\mathbf{H}_{13}$ & 0.9960 & -1.0214 \\
\hline \multirow{3}{*}{ Dohuk } & 1 & $\mathbf{H}_{5}$ & 0.9853 & $\mathbf{H}_{22}$ & 0.9942 & $-0,3949$ \\
\hline & 2 & $\mathbf{H}_{2}$ & 0.9847 & $\mathbf{H}_{20}$ & 0.9941 & $-0,4274$ \\
\hline & 3 & $\mathbf{H}_{6}$ & 0.9844 & $\mathbf{H}_{23}$ & 0.9940 & $-0,4392$ \\
\hline \multirow{3}{*}{ Sulaimania } & 1 & $\mathbf{H}_{3}$ & 0.9823 & $\mathbf{H}_{24}$ & 0.9910 & $-0,3512$ \\
\hline & 2 & $\mathbf{H}_{1}$ & 0.9799 & $\mathbf{H}_{22}$ & 0.9909 & $-0,4723$ \\
\hline & 3 & $\mathbf{H}_{6}$ & 0.9798 & $\mathbf{H}_{23}$ & 0.9908 & $-0,4886$ \\
\hline
\end{tabular}

353

\subsection{Comparison of the empirical models for Arbil}

Eleven sunshine duration models including Linear, Quadratic, Qubic, Linear, Power,

Exponential, Linear-Exponential, Linear-Logarithmic, quadratic-exponential was utilized to

estimate the global solar radiation on the horizontal surfaces as shown in Table 3.The values of the regression constants for Arbil province were calculated, and the results of these are shown in Table 4. Illustrated models that are Models $\mathrm{H} 1, \mathrm{H} 2, \mathrm{H} 3, \mathrm{H} 4, \mathrm{H} 5, \mathrm{H} 6, \mathrm{H} 7, \mathrm{H} 8, \mathrm{H} 9, \mathrm{H} 10, \mathrm{H} 11$ show accuracy with $\mathrm{R}^{2}, 0.9654,0.9767,0.9769,0.9874,0.9701,0.9637,0.9607,0.9668,0.9772,0.9734$, 0.9731 and 0.9903 , respectively. others models. In addition, in terms of data accuracy the Models H11, H4, H9, H3, H2, H10, H5, $\mathrm{H} 5, \mathrm{H} 8, \mathrm{H} 1$ and $\mathrm{H} 6$ were ranked correspondingly. However, Model-7 was the least accurate comparing to the other models. Several statistical error indicators of MBE, RMSE, $\mathrm{R}^{2}$, MPE value were applied to confirm the performance of the models. It is observed that the results have in low 
error and with an acceptable range as shown in Table 3, and it is seen that the Model-H11 had a good acceptance and high accuracy according to the other model with the coefficient of determination, $\mathrm{R}^{2}$, $(99.03 \%)$, the statistical errors were within an acceptable range of low error observed in the Model-11 and the value of MBE, RMSE, MPE are $(-0.0428) \mathrm{MJ} / \mathrm{m}^{2},(0.7767)$ $\mathrm{MJ} / \mathrm{m}^{2},(0.6737)$, respectively.

At the same time, the models depending on the other meteorological parameters were applied to Arbil province and three new models were derived for this location. In these models regression equations such as linear, cubic, exponential and logarithmic were used. The constant regression coefficients and statistical values such as MBE, RMSE, $\mathrm{R}^{2}$, MPE for the equations were given in Table 5. The Model-H12, H13, H14, H15, H16, H17, H18, H19, H20, H21, H22, H23 and $\mathrm{H} 24$ were used for Arbil province and the $\mathrm{R}^{2}$ values of these models were found as $0.9855,0.9960$, $0.9970,0.9669,0.9971,0.9958,0.9535,0.9760,0.9896,0.9897,0.9897,0.989$, and 0.9636 , respectively. The model results based on the other meteorological parameters are listed according to $\mathrm{R}^{2}$ values. The models in terms of $\mathrm{R}^{2}$ performance values were ranked as $\mathrm{H} 16, \mathrm{H} 14, \mathrm{H} 13, \mathrm{H} 17$, $\mathrm{H} 22, \mathrm{H} 21, \mathrm{H} 23, \mathrm{H} 20, \mathrm{H} 12, \mathrm{H} 19, \mathrm{H} 15, \mathrm{H} 13, \mathrm{H} 24$ and H18, respectively. When looking at the models that show the best performance in relation to the sunshine duration and the other meteorological parameters for Arbil province, it is seen that the models that are depend on other meteorological parameters have a much better performance. The first three models with the highest accuracy among the total 24 models used for the province of Arbil were found in the models including the other meteorological parameters. These models are listed as H16, H14, and H13 respectively. The comparison of measured and calculated mean solar radiation data for the Arbil province was illustrated in Fig. 4. In this figure the first three models with the highest accuracy in a total of 24 models were shown with the average monthly measured solar radiation values. When the figure was examined for this location, the selected best models for Arbil province gave very close results to the measured values. As shown in the figure, it was seen that there is a very good fit 
between the models which are connected to other meteorological parameters and measurement results.

\subsection{Comparison of the empirical models for Dohuk}

The eleven models based on sunshine duration with different regression equations such as linear, exponential, power, quadratic and logarithmic model to assess the global solar radiation as shown in Table 3 were employed. The regression coefficients and statistical indicators for estimating sunshine based global solar radiation of Dohuk province are also given in Table 4. In this work the Models-H1, H2, H3, H4, H5, H6, H7, H8, H9, H10 and $\mathrm{H} 11$ were evaluated and the coefficient of determination, $\mathrm{R}^{2}$, were $0.9837,0.9847,0.9850,0.9841,0.9853,0.9844,0.9827$, $0.9825,0.9843,0.9843$ and 0.9781 , respectively. It is founded that Model-H5 was the most appropriate among the others models. Moreover, the Models- H3, H2, H6, H9, H10, H4, H1, H7 and $\mathrm{H} 8$ were organised in terms of data accuracy respectively. Also, the Table 4 exhibits that the model H11 was the least accurate among the other models. Various statistical indicators with high acceptability such as MBE, RMSE, MPE were applied to approve the performance of the models. According to evaluation of the all models, the best acceptance with the coefficient of determination, $\mathrm{R}^{2}$, (98.53\%) indicated in the Model-H5. Table 4 illustrated that the statistical errors for Model-H5 were within an acceptable limits with low error and the value of MBE, RMSE, MPE were (0.0674) MJ/m², (0.9701) MJ/m², (-1.3529\%), respectively.

According to other meteorological parameters, thirteen models were evaluated for Dohuk province. Also, these models include three newly developed models. In addition, the accuracy of the models was evaluated by using statistical indicators such as RMSE, MBE, MPE and $\mathrm{R}^{2}$ for this city. The statistics values and constant regression coefficients based on the other meteorological parameters were given in Table 5. According to this table, the $\mathrm{R}^{2}$ values of H12, H13 ,H14, H15, H16, H17, H18, H19, H20, H21, H22, H23 and H24 models was found as 0.9903, 0.9703, 0.9886, 0,9831, 0.9892, 0.971, 0.9717, 0.9668, 0.9941, 0.9936, 0.9974, 0.9940 and 0.9924 , respectively. 
419 Also the models in this table are sorted by accuracy. Accordingly, the order of accuracy of the models was found as H22, H20, H23, H24, H12, H16, H14, H5, H17, H18, H13 and H19. Among

421 these models, the newly developed H22 model has the highest precision. The results of statistics

422

423 indicators such as $\mathrm{R}^{2}$, MBE, RMSE, and MPE used for this model were found as (0.9942), (0.0789), (0.5752), (0.4788), respectively. For the Dohuk city, a total of twenty four models were investigated, depending on the sunshine duration and the other meteorological parameters. The first three models with the highest accuracy among these models were found as H22, H20, H23, respectively. These three models are also based on the other meteorological parameters. In this study, the measured average monthly solar radiation values for Arbil and Dohuk were compared with the results of the first three models that have highest accuracy among twenty four models and it is given in Fig. 4 and Fig. 5. As can be seen from the figures, the calculated results based on the other meteorological parameters were harmony with very high accuracy to actual results.

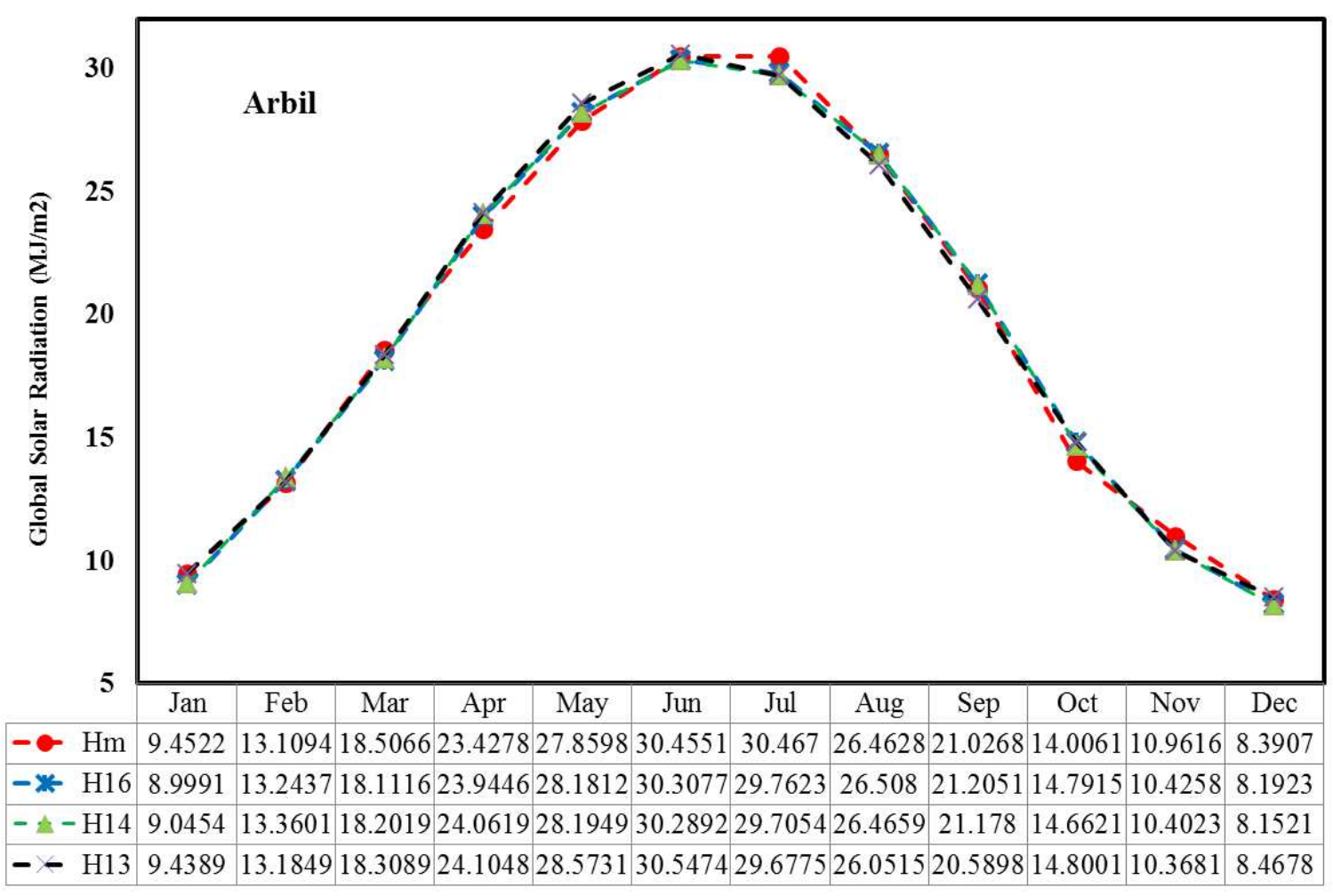

Months of the year

Figure 4. Monthly average measured and calculated global solar radiation for Arbil 


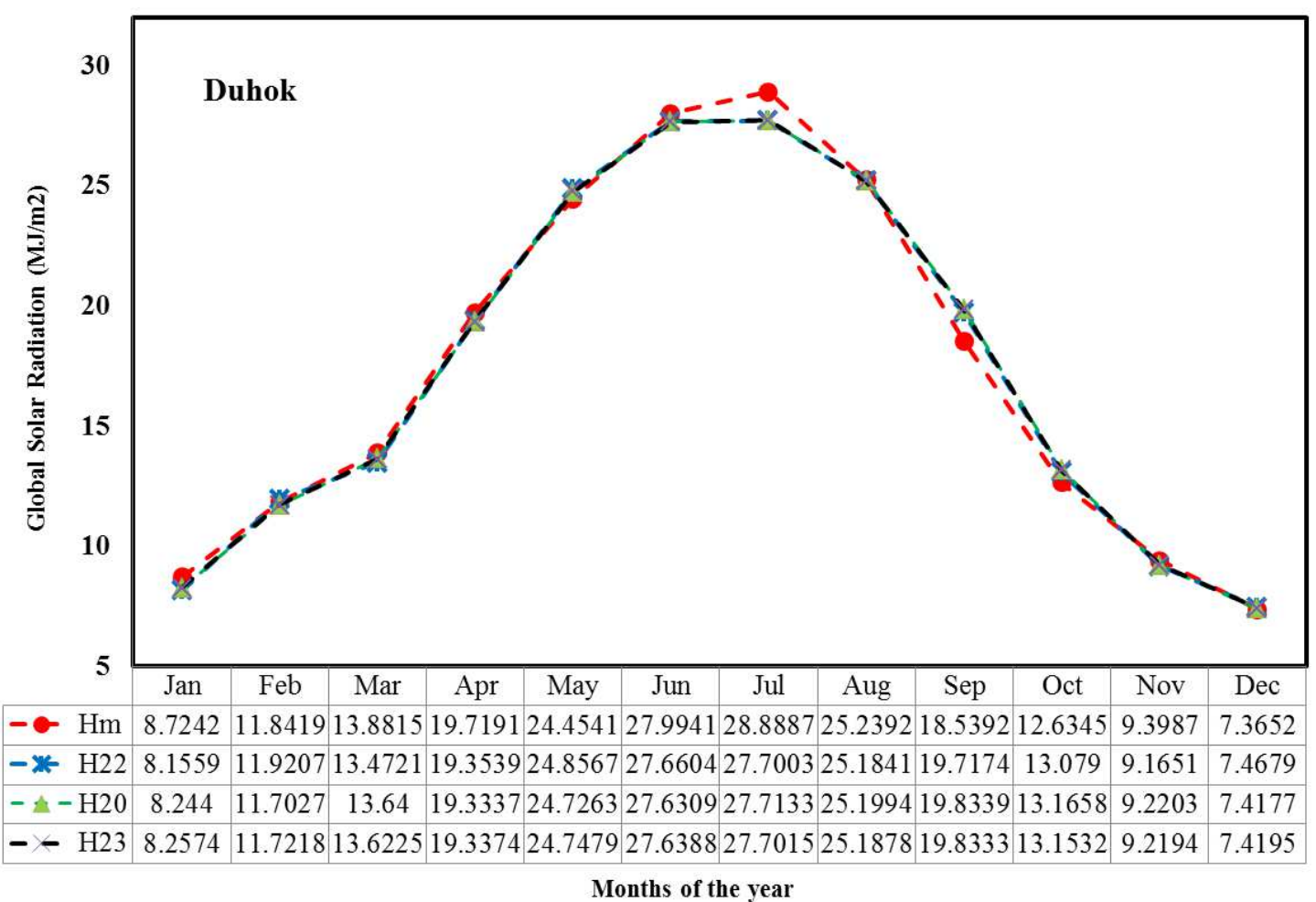

434

435

436

437

438

439

440

441

442

443

444

445

446

447

448

449

Figure 5. Monthly average measured and calculated global solar radiation for Dohuk

\subsection{Comparison of the empirical models for Sulaimania}

The eleven sunshine duration models that are $\mathrm{H} 1, \mathrm{H} 2, \mathrm{H} 3, \mathrm{H} 4, \mathrm{H} 5, \mathrm{H} 6, \mathrm{H} 7, \mathrm{H} 8, \mathrm{H} 9, \mathrm{H} 10$, and $\mathrm{H} 11$ is utilised to estimate the global solar radiation on the horizontal surface for Sulaimania city. The values of the regression constants and statistical indicators were calculated as shown in Table 4 . The coefficient determination $\left(\mathrm{R}^{2}\right)$ of these models was found as $0.9799,0.9787,0.9823,0.9786$, $0.9775,0.9798,0.9782,0.9787,0.9778,0.9782,0.9775,0.9776$, and 0.9765 , respectively. The results revealed that Model-3 had the most appropriate data in comparison to the others models. In addition, in terms of data accuracy the Models H1, H6, H8, H2, H4, H7, H9, H5, H10 and H11 were ranked respectively. It was observed that the Model-11 had the least accurate comparing with the other models. To confirm the performance of the models, a number of statistical error indicators value like MBE, RMSE and MPE value were employed. The results of all model shows low error with a standard range as illustrated in Table 4. The Model-3 indicated good acceptance and high 
accuracy with the coefficient of determination, $\mathrm{R}^{2}$, (98.23\%). For the Model-3, the value of MBE,

451

452

453

454

455

456

457

458

459

460

461

462

463

464

465

466

467

468

469

470

RMSE, and \%MPE were (-0.1291) MJ $/ \mathrm{m}^{2},(1.0229) \mathrm{MJ} / \mathrm{m}^{2},(-0.3389 \%)$, respectively.

Thirteen models were investigated for Sulaimania province depending on other meteorological parameters. These models include three new models that are H17, H22 and H24. The results of various statistical indicators such as RMSE, MBE, MPE, and $\mathrm{R}^{2}$ for all models used in this study and the constant regression coefficients developed for each model are given in Table 5. According to this table the $\mathrm{R}^{2}$ values of the H12, H13, H14, H15, H16, H17, H18, H19, H20, $\mathrm{H} 21, \mathrm{H} 22, \mathrm{H} 23$, and H24 models was found as $0.9894,0.9813,0.9881,0.9771,0.9903,0.9830$, 0.9796, 0.9781, 0.9907, 0.9908, 0.9909, 0.9908, 0.9910, respectively. Also, these models are ranked according to the value of $\mathrm{R}^{2}$. According to accuracy, the models are ranked as $\mathrm{H} 24, \mathrm{H} 22$, H23, H21, H20, H16, H12, H14, H17, H13, H18, H19, and H15. Among the twenty four models, the newly developed $\mathrm{H} 24$ model has been found to be the most accurate model. The statistical values that are $\mathrm{R}^{2}$, MBE, RMSE and MPE of this model are found as $0.9910,-0.0880,0.6717$, 0.2141, respectively. A total of twenty four models were examined for Sulaimanai province. Among these models, the models based on the other meteorological parameters yielded higher sensitivity results than the models based on sunshine duration. In addition, the H24 and H22 models which are newly developed according to other meteorological parameters, has given the best results within the all models. The first three models with the best results among these models and the average monthly solar radiation measurement results for Sulaimania are given in Figure 6. As can be seen from the figure, the results of the other meteorological parameter models and the actual measurement results are in good agreement with each other. 


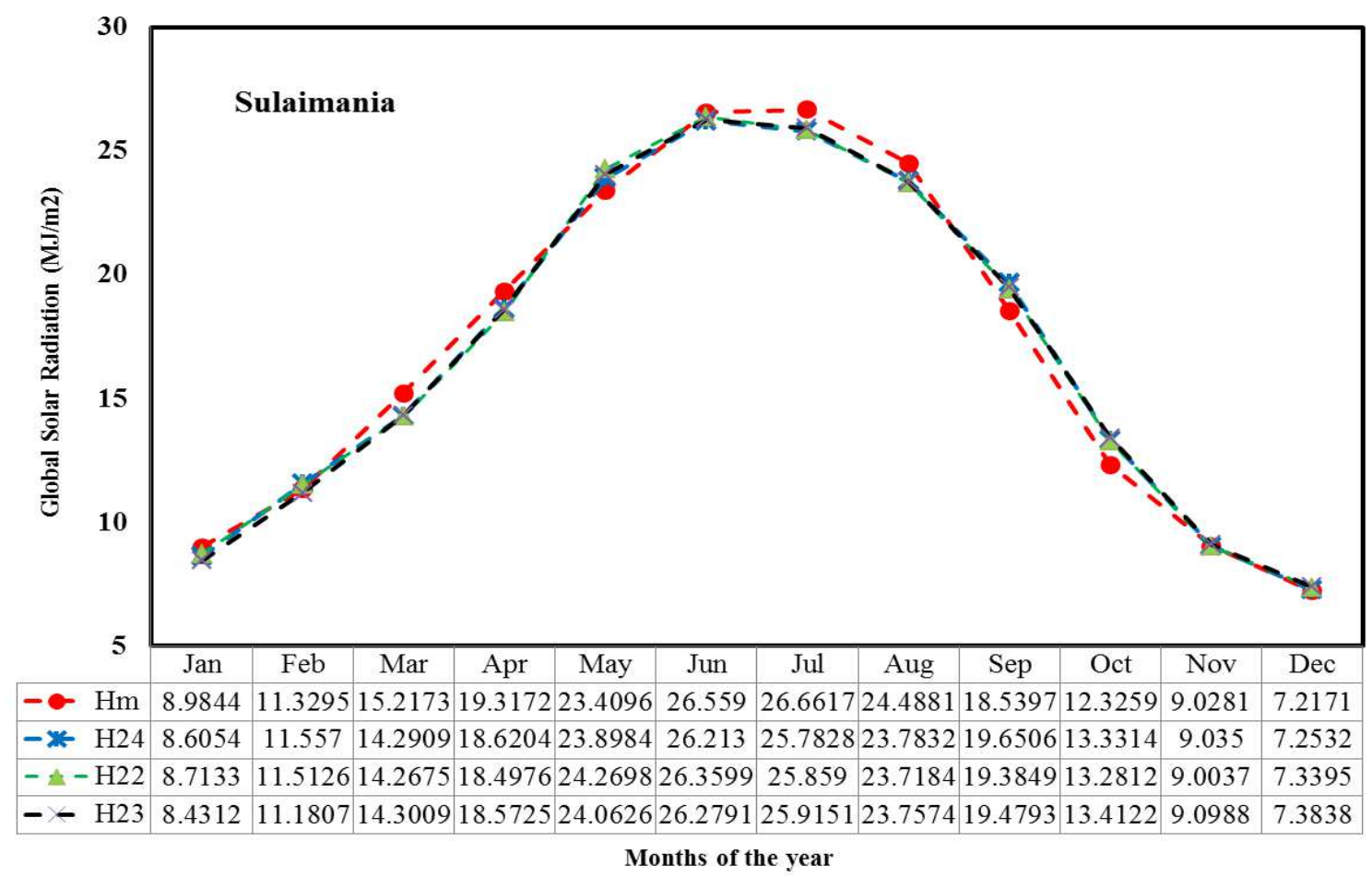

471

472

473

474

475

476

477

478

479

480

481

482

483

484

485

486

487

Figure 6. Monthly average measured and calculated global solar radiation for Sulaimani

While comparing the predictions of our model with other reported models, we found that the results of the model proposed here are promising. For example, Besharat et al. (2013) chronologically collected the extensive models of global solar radiation in the literature and divided them into four categories; sunshine duration, cloud, temperature and other meteorological parameters based models. In this study, the evaluated models were compared with each other. As a result of this, the other meteorological parameters based models has better performance than the other three models. El-Mghouchi (2016) evaluated his study according to the value of $\mathrm{R}^{2}$. In this study, the best value according to $\mathrm{R}^{2}$ value was found to be 0.9572 . In addition, in the Yanıktepe study (2015), by examining the models based on the different sunshine duration models, the $\mathrm{R}^{2}$ value of the new proposed model was 0.8883 that is the best results in the all models. Viktor (2016), worked to estimate the solar radiation coming to earth as only a function of temperature. He stated that if more meteorological data such as temperature, precipitation, relative humidity, latitude and longitude were used in their study, it would be possible to estimate daily solar radiation with higher accuracy. 

in this study. Correlation coefficients are different for each studied region and should be calculated for each region. Globally correlated coefficients show less sensitivity compared to local results (Almorox and Hontoria 2004). In addition, there are new correlation coefficients for the models used in many of the studies (Manzano 2015; Bakirci 2009; Adaramola 2012).

Also, comparisons were made at different locations to test the accuracy of these models divided into two categories that are sunshine duration and meteorological parameter. According to conclusion, the results obtained from the other meteorological parameters for each of the three regions performed better than the results of the sunshine duration model for every location studied. In summarizing the model results, we propose that the model described here can be potentially useful in predicting global solar radiation at different locations due to easily found primary input parameters required, and these data are easily available for any location in the world.

\section{Conclusion}

The results of the correlation are tested by the statistical indicator to define the performance at low error and at high accuracy. In Arbil: Model-16, $\mathrm{H}=\mathrm{a}+\mathrm{b}\left(\mathrm{S} / \mathrm{S}_{\circ}\right)+\mathrm{c} \sin (\delta)+$ dT was observed as the best models. In Dohuk, the Model-22, $\mathrm{H} / \mathrm{H}_{\circ}=\mathrm{a}+\mathrm{b}\left(\mathrm{S} / \mathrm{S}_{\circ}\right)+$ $c\left(\mathrm{~T}_{\min } / \mathrm{T}_{\max }\right)^{-1}+\mathrm{dRH}$, was observed as the best models. In Sulaimania, Model-24, $\mathrm{H} / \mathrm{H} \circ=$ $\mathrm{a}+\mathrm{b} \ln \Delta \mathrm{T}+\mathrm{c}\left(\mathrm{T}_{\min } / \mathrm{T}_{\max }\right)+\mathrm{dRH}$, was observed as the best models.

For Arbil location, the H11, H4 and H9 models has showed the best performance among the models based on sunshine duration, respectively. The $\mathrm{R}^{2}$ values of these models were calculated as $0.9903,0.9874$ and 0.9772 , respectively. However, when looking at the models dependent on the other meteorological parameter models for the Arbil city, H16, H14 and H13 models show much better performance than the sunshine duration models with $\mathrm{R}^{2}$ values of $0.9971,0.9970$ and 0.9960 , respectively. Likewise, H22 and H24 models, among the other meteorological parameter models, 
513 showed the best performance according to sunshine duration models with $\mathrm{R}^{2}$ values of 0.9942 and

5140.9910 for the cities of Dohuk and Sulaimania, respectively.

515 The presented study showed that the models developed based on other meteorological 516 parameters yielded higher accuracy than models based on sunshine duration. Therefore, we propose

517

518

519

520

521

522

523

524

525

526

527

528

529

530

531

532

533

534

535

536

537

538

539

540

541

542

543

544

545

546

547

548

549

550

551

552

553

554

555

556 that the approach described here can be more useful for predicting global solar radiation. In summarizing the model results, we recommend that the model described here can be potentially useful in predicting global solar radiation at different locations due to easily found primary input parameters required, and these data are easily available for any location in the world.

Author contribution: İU: supervision, investigation, writing review and editing, KMK preparing, and writing. All authors read and approved the final version of this manuscript.

Data availability All data presented herein are included in this published article.

\section{Declarations}

Ethical statement: Not applicable.

Consent to participate: Not applicable.

Consent for publication: Not applicable.

Competing interests: The authors declare no competing interests.

Funding: Not applicable. 
Abdalla, Y.A.G. 1994. New correlation of global solar radiation with meteorological parameters for Bahrain. International Journal of Solar Energy, 16, 111- 120.

Adaramola M.S. 2012. Estimating global solar radiation using common meteorological data in Akure, Nigeria. Renewable Energy, 47, 38-44.

Allen, R.G. 1997. Self-calibrating method for estimating solar radiation from air emperature. Journal of Hydrologic Engineering, 2:56-67.

Al-Douri, Y., F.M. Abed. 2016. Solar energy status in Iraq: Abundant or not-Steps forward. $J$. of Renew. and Sust. Energy. 8,025905-19.

Almorox, J., C. Hontoria. 2004. Global solar radiation estimation using sunshine duration in Spain. Energy Convers. Manag., 45, 1529-1535.

Angstrom A. 1924. Solar and terrestrial radiation. Quart J. Roy. Met. Soc., 50, 121-125.

Annandale, J.G., N.Z. Jovanic, N. Benade, R.G. Allen. 2002. Software for missing data error analysis of Penman-Monteith reference evapotranspiration. Irrigation Science. 21, 5767.

Ampratwum, D.B., A.S.S. Dorvlo. 1999. .Estimation of solar radiation from the number of sunshine hours. Applied Energy. 63,161-167.

Bakirci, K. 2009. Models of solar radiation with hours of bright sunshine: a review. Renewable and Sustainable Energy Reviews 13, 2580-2588.

Bakirci, K. 2009. Correlations for estimation of daily global solar radiation with hours of bright sunshine in Turkey. Energy, 34, 485-501.

Bamehr. S., S. Sabetghadam. 2021. Estimation of global solar radiation data based on satellitederived atmospheric parameters over the urban area of Mashhad, Iran. Environmental Science and Pollution Research 28:7167-7179.

Benghanem, M., A. Mellit., S.N. Alamri. 2009. ANN-based modelling and estimation of daily global solar radiation data: A case study. Energy Convers. Manag., 50, 1644-1655.

Besharat, F., A.A. Dehghan., A.R. Faghih. 2013. Empirical models for estimating global solar radiation: A review and case study. Renewable and Sustainable Energy Reviews, 21, 798821.

Birol, F., 2017. CO2 Emissions from fuel combustion highlights. Int. Energy Agency.

Chen, J.L., G.S. Li. 2013. Estimation of monthly average daily solar radiation from measured meteorological data in Yangtze River Basin in China. Int. J. Climatol., 33(2), 487-498.

Chen, R., K. Ersi, J. Yang, S. Lu, W. Zhao. 2004., Validation of five global radiation models 
with measured daily data in China. Energy Convers. Manag., 45,1759-769.

Chukwujindu, N.S., 2017. A comprehensive review of empirical models for estimating global solar radiation in Africa. Renew. Sust. Energy Reviews. 78, 955-995.

Duffie, J.A., W.A. Beckman. 2013. Solar Engineering of Thermal Processes. New Wiley.

Elagib, N.A., M.G. Mansell. 2000. New approaches for estimating global solar radiation across Sudan. Energy Convers. Manag., 41, 419-434.

El-Metwally M. 2005. Sunshine and global solar radiation estimation at different sites in Egypt. J Atmos Solar-Terrestrial Phys 67,1331-1342.

El-Sebaii, A.A., A.A. Al-Ghamdi, F.S. Al-Hazmi, A. Faidah. 2009. Estimation of global solar radiation on horizontal surfaces in Jeddah, Saudi Arabia. Energy Policy, 37, 3645-3649.

El Mghouchi, Y., Z. El Bouardi, T. Choulli, T. Ajzoul. 2016. Models for obtaining the daily direct, diffuse and global solar radiations. Renewable and Sustainable Energy Reviews. 56, 87-99.

Ehnberg, J.S.G., M.H.J. Bollen. 2005. Simulation of global solar radiation based on cloud observations. Solar Energy. 78,.157-162.

Fan, J., B. Chen, L. Wu, F. Zhang, X. Lu, Y. Xiang. 2018. Evaluation and development of temperature-based empirical models for estimating daily global solar radiation in humid regions. Energy, 144, .903-914.

Glower, J., J.S.G. McGulloch. 1958. The empirical relation between solar radiation and hours of sunshine. Quarterly Journal of the Royal Meteorological Society. 84, 172.

Hassan, E.G., M.E. Youssef, Z.E. Mohamed, A.A. Mohamed A.A. Hanafy. 2016. New Temperature-based Models for Predicting Global Solar Radiation. Applied Energy. 179, 437-450.

Hunt, L.A., L. Kuchar, C.F. Swanton. 1998. Estimation of solar radiation for use in crop modeling. Agric. and Forest Meteo. 91, 293-300.

Isikwue, B., S. Dandy, M. Audu. 2013. Testing the performance of some empirical models for estimating global solar radiation over Makurdi, Nigeria. Journal of Natural Sciences Research. 165-170

Jiandong, L., L. Hans, C. Deliang, Z.X. Zhou, G.N. Flerchinger, Y. Qiang., at al. 2015. Changes in the relationship between solar radiation and sunshine duration in large cities of China. Energy, 82. 589-600.

Jahania, B., Y. Dinpashoha, A.R. Nafchib. 2017. Evaluation and development of empirical models for estimating Daily solar radiation. Renew. and Sust. Energy Rev., 73, 878-891.

Janjai, S., P. Pankaewa, J. Laksanaboonsong, P. Kitichantaropas. 2011. Estimation of solar radiation over Cambodia from long-term satellite data. Renew. Energy. 36, 1214-1220.

Khorasanizadeh, H., K. Mohammadi. 2013. Introducing the best model for predieting the monthly 
mean global solar radiation over six major cities of Iran. Energy. 51, 257-266.

Li, H., W. Maa, Y. Lian., X. Wang., L. Zhao. 2011. Global solar radiation estimation with sunshine duration in Tibet China. Renew. Energ. 36, 3141-3145.

Li, M.F., F. Li., H.B. Liu, P.T. Guo, W. Wu. 2013. A general model for estimation of daily global solar radiation using air temperatures and site geographic parameters in Southwest China. Journal of Atmospheric and Solar-Terrestrial Physic. 92:145-150.

Liu, Y., Y. Zhou, D. Wang, Y. Wang, Y. Li, Y. Zhu. 2017. Classification of solar radiation zones and general models for estimating the daily global solar radiation on horizontal surfaces in China. Energy Convers. Manag. 154, 168-179.

Liu, X., X. Mei, Y. Li, Q. Wang, J.R. Jensen, Y. Zhang, J.R. Porter. 2009. Evaluation of temperature-based global solar radiation models in China. Agricultural and Forest Meteorology. 149, 1433-1446.

Liu, D.L., B.J. Scott. 2001. Estimation of solar radiation in Australia from rainfall and temperature observations. Agric.and Forest Meteo., 106, 41-59.

Makade, R.G., S. Chakrabarti, B. Jamil. 2021. Development of global solar radiation models: A comprehensive review and statistical analysis for Indian regions. Journal of Cleaner Production, 293, 126208

Manzano,A., M.L. Martín, F. Valeroa, C. Armenta. 2015. A single method to estimate the daily global solar radiation from monthly data. Atmospheric Research. 166, 70-82.

Newland, F.J., 1988. A study of solar radiation models for the coastal region of south China. Solar Enery. 31, 227-35.

Ogelman, H., A. Ecevit, A.E. Tasdemiroglu. 1984. A new method for estimating solar radiation from bright sunshine data. Solar Energy. 33, 619-626.

Paulescu, M., P. Gravila, E. Tulcan. 2008. Fuzzy logic algorithms for atmospheric transmittances of use in solar energy estimation. Energy Convers. Manage. 49, 3691-3697.

Peng L, B. Miloud, M. Beatrice, C. Jean-Pierre, D. Mathieu L. Qi. 2020. Daily Surface Solar Radiation Prediction Mapping Using Artificial Neural Network: The Case Study of Reunion Island. J. Sol. Energy Eng. 142(3): 031003

Prescott, J.A. 1940. Evaporation from water surface in relation to solar radiation. Transactions of the Royal Society of Australia 1940;46:114-118.

Rehman, S., M. Mohandes. 2008. Artificial neural network estimation of global solar radiation using air temperature and relative humidity. Energy Policy, 36, 571-576.

Samuel, T.D.M.A. 1991. Estimation of global radiation for Sri Lanka. Solar Energy, 47, $.333-337$. 
Suehrcke, H., S. Ross, K.G.T. Bowden. 2013. Relationship between sunshine duration and solar radiation. Solar Energy, 92, 160-171.

Sen, Z. 2007. Simple nonlinear solar irradiation estimation model. Renewable Energy, $32,342-350$.

Su, G., S. Zhang, M. Hu, W. Yao, Z. Li, Y. Xi. 2022. The modified layer-by-layer weakening solar radiation models based on relative humidity and air quality index, Energy, 239: 122488.

Swartman, R.K., Q. Ogunlade. 1967. Solar radiation estimates from common parameters. Solar Energy, 11,170-182.

Tao H., A. A. Ewees, A. O. Al-Sulttani, U. Beyaztas, et al. 2021. Global solar radiation prediction over North Dakoa using air temperature: Development of novel hybrid intelligence model, Energy Reports 7:136-157.

Togrul, I.T., E. Onat. 1999. A study for estimating solar radiation in Elazig using geographical and meteorological data. Energy Convers. Manag., 40,.1-12.

Victor H. Quej, J. Almorox, M. Ibrakhimov, L. Saito. 2016. Empirical models for estimating daily global solar radiation in Yucatán Peninsula, Mexico. Energy Conversion and Management, 110, 448-456.

Yao, W., Z. Li, Y. Wang, F. Jiang, L. Hu. 2014. Evaluation of global solar radiation models for Shanghai. China. Energy Convers Manag., 84, 597-612.

Yaniktepe, B., Y.A. Genc. 2015. Establishing new model for predicting the global solar radiation on horizontal surface. International Journal of hydrogen energy, 40, 1527- 1528.

Zhou, Z., L. Wang, A. Lin, M. Zhang, Z. Niu. 2018. Innovative trend analysis of solar radiation in China during1962-2015. Renew. Energy, 119, 675-689.

560

561

562

563

564

565

566

567

568

569

\section{Figure Captions}

Figure 1. Measurement components of solar radiation, a) Sunshine duration sensors, b)

QMS101pyranometer, c) installation of Sunshine duration, Pyranometer QMS101 and HMP155 device, d) AWS data Logger model QML201

Figure 2. The map of the selected locations

Figure 3. Monthly average meteorological parameters for Arbil (a), Dohuk (b) and Sulaimania (c) Figure 4. Monthly average measured and calculated global solar radiation for Arbil

Figure 5. Monthly average measured and calculated global solar radiation for Dohuk 
$570 \quad$ Figure 6. Monthly average measured and calculated global solar radiation for Sulaimani

571

\section{$572 \quad \underline{\text { Table Captions }}$}

573

574 Table 1. Technical information of Pyranometer model QMS101.

575 Table 2. Geographic locations of the studied region

576 Table 3. Models used and newly developed model

577 Table 4. Results of sunshine duration models with the statistical indicators and correlation $578 \quad$ coefficient

579 Table 5. Results of the other meteorological parameters models with the statistical indicators and 580 correlation coefficient

581 Table 6. Comparison of the best of sunshine duration models and the other meteorological 582 parameter models 